\title{
EFFECT OF FOLIAR CALCIUM CHLORIDE TREATMENT ON THE LEVEL OF CHLOROGENIC ACID, $\beta$-CAROTENE, LUTEIN AND TOCOPHEROLS IN LETTUCE (Lactuca sativa $\mathrm{L}$.)
}

\author{
Irena Perucka, Katarzyna Olszówka \\ Department of Chemistry, Research Group on Phytochemistry, University of Life Sciences, \\ Akademicka 15, 20-950 Lublin, Poland \\ email: kasiaolszowka@wp.pl
}

Received: 10.11 .2010

\begin{abstract}
The aim of the presented study was to determine the effect of foliar application of $\mathrm{CaCl}_{2}$ on the level of $\beta$-carotene, lutein, tocopherols and phenolic compounds in the leaves of lettuce cv. Omega (Lactuca sativa L.). The experiments were conducted in the greenhouse of the Faculty of Cultivation and Fertilisation of Horticultural Plants, University of Life Sciences in Lublin. During the growing period, 7 and 14 days before harvest, the plants were treated with a solution of $\mathrm{CaCl}_{2}$ with concentrations of $0.1 \mathrm{M}$ and $0.2 \mathrm{M}$. Plants sprayed with water were the control treatment in the experiment. Analyses were performed on whole leaves and the blade without midrib. The obtained results indicate that the leaves of lettuce cv. Omega are a good source of phenolic compounds, carotenoids and tocopherols. The dominant carotenoid in lettuce cv. Omega was $\beta$-carotene. Foliar application of $\mathrm{CaCl}_{2}$ on the plants did not have any significant effect on the level of $\beta$-carotene and lutein in the whole leaves. The contents of tocopherols, total phenolic compounds and chlorogenic acid were dependent on the concentration of $\mathrm{CaCl}_{2}$. The application of $0.1 \mathrm{M} \mathrm{CaCl}_{2}$ solution in the plants resulted in a decrease in the level of total phenolic compounds and chlorogenic acid, and an increase in tocopherol content. However, the treatment of the plants with $0.2 \mathrm{M} \mathrm{CaCl}_{2}$ solution caused a lowering of the concentration of tocopherols and an increase in the content of chlorogenic acid and total phenolic compounds.
\end{abstract}

Key words: Lactuca sativa, $\mathrm{CaCl}_{2}$ treatment, $\beta$-carotene, lutein, vitamin E, phenolic compounds

\section{INTRODUCTION}

In recent years, there has been a continuous increase in the consumption of leafy vegetables, which is a result of changes in the lifestyle of consumers
(Ragaert et al. 2004; Ferrante and Maggiore, 2007; Martin-Dian a et al. 2007). Diets rich in vegetables and fruits reduce the risk of occurrence of chronic diseases (Ste in metz and Potter, 1991; B lock et al. 1992), because they are sources of bioactive phytochemical compounds (Moelle r et al. 2000; Niizu and Rodriguez-A maya, 2005; C a ldwe 11 and B ritz, 2006). Lettuce is one of the important world-wide dietary products available the year round which include phenolic compounds and carotenoids such as lutein and $\beta$-carotene as well as of vitamin $\mathrm{E}$ (Nicolle et al. 2004).

The antioxidant activity in lettuce arises from phenolic compounds such as flavonoids and derivatives of caffeic acid. One of them is chlorogenic acid, which is located mainly in the green parts of plants (Olth of et al. 2001). This acid is characterised by not only antioxidant activity but also anticancerogenic properties (Gontier et al. 2003); it also decreased the level of choresterol and glucose in the blood of experimental animals (Rodriques de Sotillo and $\mathrm{Hadley}$, 2002).

Carotenoids are a group of natural pigments whose importance is related to reducing the risk of occurrence of degenerative diseases, such as cancers, cardiovascular disorders, cataract, and macular degeneration. They are sensitive to the effect of numerous factors, such as light and heat $(\mathrm{Hart}$ and $\mathrm{Scott}$, 1995) as well as growth conditions (Kimura and Rodriguez-A maya, 2003; Caldwell and B ritz, 2006).

Another group of components that are important in terms of dietary properties are tocopherols. They are a group of lyophilic antioxidants, synthesised 
by photosynthetic organisms, occurring primarily in leaves and seeds. Tocopherols are considered to be antioxidants taking part in the protection of stability of cell membranes. Their antioxidant role is attributed to inhibition of peroxidation of membrane lipids and to scavenging of reactive forms of oxygen ( $\mathrm{Fryer}$, 1992; Tre bst et al. 2002; Kruk et al. 2005). Tocopherols also perform other functions, among which we can include the transport of sugars from the leaves to other parts of plants ( $\mathrm{Ruperez}$ et al. 2001; Munne-Bosch and Alegre, 2002; Trebst et al. 2002; Hofius et al. 2004; Kruk et al. 2005; S z y mańska and Kruk, 2008).

Lettuce, and especially butter lettuce, is prone to damage. To ensure high quality of freshly cut vegetables preserving the correct colouring and preventing the browning of tissues, a variety of processes are employed. The plants are subjected to various treatments during their growth or after harvest. Such processes comprise mainly biochemical transformations related with the occurrence of plant browning (D e g l' In nocenti et al. 2005, 2007). One of the causes for leaf browning is a deficit of calcium ions. The most effective method is foliar supplementation of this element. Among the calcium compounds that are used for plant spraying, calcium chloride is absorbed the best (Michałojć and Horodko, 2006). It has been found that a high content of calcium in fruits reduces the rate of respiration, delays ageing ( $\mathrm{Fer}$ $\mathrm{g} \mathrm{u}$ s o n , 1984). Our earlier studies showed that foliar application of $\mathrm{CaCl}_{2}$ solution on plants of sweet and hot peppers at the seedling stage caused accelerated ripening of the fruits but did not have any significant effect on the level of vitamins. A tendency towards an increase in the content of tocopherols in the fruits of plants treated with $\mathrm{CaCl}_{2}$ was only observed ( $\mathrm{Pe} \mathrm{r} \mathrm{u} \mathrm{-}$ $\mathrm{cka}$ and Materska, 2004).

The objective of the study presented here was to determine the effect of $\mathrm{CaCl}_{2}$ applied on lettuce at the phase of growth on its quality expressed by the contents of $\beta$-carotene, lutein, tocopherols and phenolic compounds and their antioxidant activities.

\section{MATERIAL AND METHODS}

The experimental material was lettuce cv. Omega. The study was performed in the form of a pot experiment, in the greenhouse of the Faculty of Cultivation and Fertilisation of Horticultural Plants, University of Life Sciences in Lublin, in 2006. The greenhouse temperature was $18^{\circ} \mathrm{C}$ during the night and $23^{\circ} \mathrm{C}$ during the day. $2 \mathrm{~L}$ pots were filled with transitional peat with $\mathrm{pH}=5.4$, limed to $\mathrm{pH}=6.4$ with calcium carbonate . The addition of nutrients was in conformance with the requirements for greenhouse cultivation of lettuce and contained $0.7 \mathrm{~g} \mathrm{~N}, 1.5 \mathrm{~g} \mathrm{~K}$, and $0.45 \mathrm{~g} \mathrm{Mg}$ per plant (P e r u cka et al. 2007). After two and three weeks from planting in the pots, the plants were sprayed with a solution of $\mathrm{CaCl}_{2}$ in various amounts. The plants were divided into three experimental series. One series was given foliar feeding in the form of spraying with $\mathrm{CaCl}_{2}$ solution at a concentration of $0.1 \mathrm{M}$ (Ca1), another one with a solution with a concentration of $0.2 \mathrm{M}(\mathrm{Ca} 2)$, which corresponded to $55 \mathrm{mg}$ and $110 \mathrm{mg}$ per plant, respectively, while the third series comprised control plants sprayed with water.

The chemical analysis included the assay of phenolic levels in whole leaves of lettuce cv Omega, whereas carotenoid and tocopherol contents in whole leaves and in the blades after removal of the midrib.

Total phenolic compounds and chlorogenic acid were analysed using freeze-dried material, while the carotenoids and tocopherols were determined on fresh material immediately after harvest.

\section{Isolation and quantification of total phenolic compounds}

The fraction containing phenolic compounds was isolated from plant material according to the method given by Chen et al. 2001 and by Nicolle et al. 2004, after certain modifications. Freeze-dried samples of lettuce $(250 \mathrm{mg})$ were homogenised with $50 \mathrm{ml}$ of a $70 \%$ aqueous solution of methanol for $30 \mathrm{~min}$. The extract obtained was filtered and evaporated under reduced pressure (220-150 mbar) till dry at a temperature of $47^{\circ} \mathrm{C}$. Next, the dry residue was dissolved in water $(5 \mathrm{ml})$ and purified on a Sep-Pak cartridge with RP-18 stationary phase which was preconditioned with methanol $(5 \mathrm{ml})$ and $0,03 \mathrm{M} \mathrm{HCl}$ $(10 \mathrm{ml})$. The obtained extract was loaded onto the cartridge and washed with $10 \mathrm{ml}$ of $0.03 \mathrm{M} \mathrm{HCl}$. The adsorbed fraction of phenolic compounds was eluted with $5 \mathrm{ml}$ of $60 \%$ methanol. The determination of total phenolic compounds was made using the Folin-Ciocalteau reagent, following the method given by Nicolle et al. 2004 with modifications. The Folin reagent was diluted with water at $1: 10$, and a $3.2 \mathrm{ml}$ solution of $\mathrm{Na}_{2} \mathrm{CO}_{3}\left(75 \mathrm{~g} \mathrm{x} \mathrm{l}^{-1}\right)$. Absorbance of the mixture obtained was measured after $1 \mathrm{~h}$, at a wavelength of $760 \mathrm{~nm}$, on a Shimadzu UV - 160A spectrophotometer. Total phenolic compounds were determined on the basis of the standard chlorogenic acid solution (within the range of $0.0015-0.1 \mathrm{mg} \mathrm{x} \mathrm{ml}^{-1}$ ) and their contents were expressed as chlorogenic acid equivalent.

\section{Determination of chlorogenic acid}

The determination of chlorogenic acid was made with the use of the method proposed by Llorach et al. 2004. The splitting of the fraction containing phenolic compounds was conducted by HPLC method 
using a Knauer WellChrom chromatograph with UVVis detection. The separation was made on a RP 18 Eurosil Bioselect 300 column, with dimensions of $300 \times 4 \mathrm{~mm}$, and particle diameter of $5 \mu \mathrm{m}$. The following system of solvents was used as the mobile phase: A - 5\% water solution of $\mathrm{HCOOH}, \mathrm{B}-$ acetonitrile, with gradient elution, starting with $90 \% \mathrm{~A}$ and $10 \% \mathrm{~B}$, in $25 \mathrm{~min} 82 \% \mathrm{~A}$ and $18 \% \mathrm{~B}$, in $40 \mathrm{~min} .55 \% \mathrm{~A}$ and $45 \% \mathrm{~B}$ in isocrate to $50 \mathrm{~min}$. The flow rate of the mobile phase was $1 \mathrm{ml} / \mathrm{min}$ and the detection was made at a wavelength $330 \mathrm{~nm}$. Identification and quantification of chlorogenic acid were performed through comparison with retention time and plotting of a standard curve (within the range of $0.00156-0.025 \mathrm{mg} \mathrm{x} \mathrm{ml}^{-1}$ ), which was carried out under the same conditions as those for the analysed samples (Figs 1-2).

\section{Antioxidant activity assay}

Antioxidant activity was determined by the spectrophotometric method according to Nicolle et al. 2004. The free radical scavenging activity using the free radical of DPPH (1,1-diphenyl-2-picrylhydrazyl) was evaluated by measuring the variation in absorbance at $515 \mathrm{~nm}$ after $30 \mathrm{~min}$. of reaction in a glass cuvette at room temperature. The reaction was started by adding the sample extract $(0.5 \mathrm{ml})$ to the cuvette containing $2 \mathrm{ml}$ of methanol solution of free radical DPPH $\left(1 \times 10^{-4} \mathrm{M}\right)$. The reaction was followed with a UV - Vis Varian spectrophotometer. The percentage inhibition was evaluated according to equation:

$$
A A=\left(1-\frac{A_{p}}{A o}\right) \cdot 100
$$

$A_{p}$ - absorbance of the sample

$A_{o}^{p}$ - absorbance of DPPH (blank)

\section{Isolation of carotenoids and tocopherols}

The fraction containing carotenoids and tocopherols was obtained after homogenization of the plant material with a mortar and silicon dioxide in acetone $(70 \mathrm{ml})$ that was cooled to $-4^{\circ} \mathrm{C}$. Petroleum ether $(70 \mathrm{ml})$ was added to the acetone extract obtained, and next it was washed continuously with water to remove the acetone. The ether extract obtained was dehydrated with anhydrous sodium sulphate (VI) and concentrated to $10 \mathrm{ml}$. The samples prepared as above were used for the assay of the contents of carotenoids and tocopherols.

\section{Evaluation of carotenoids}

The content of carotenoids was determined with the method of column chromatography, using calcium oxide as the adsorbent. $\beta$-Carotene was eluted as the first carotenoid with petroleum ether used as the mobile phase, and the second one was lutein eluted with a $5 \%(\mathrm{v} / \mathrm{v})$ solution of acetone in petroleum ether $(\mathrm{P} \mathrm{e}$ r u c k a , 1996). The carotenoid contents were analysed spectrophotometrically by absorption measurements at $450 \mathrm{~nm}$ and $470 \mathrm{~nm}$ for $\beta$-carotene and lutein fractions, respectively, using the spectrophotometer UV-Vis Shimadzu - 160A.

\section{Vitamin E determination}

The content of vitamin $\mathrm{E}$ was determined using the modified method of Müller-Mulot 1968. The petroleum ether extract obtained as described above was evaporated till dryness at $35^{\circ} \mathrm{C}$ under reduced pressure, and the dry residue was dissolved in ethanol. The extract obtained was purified on a silica gel column by washing with hexane to remove chlorophylls and carotenoids. The fraction containing tocopherols was eluted with a mixture of hexane with acetone (4:1). The extract obtained was evaporated at $35^{\circ} \mathrm{C}$, under reduced pressure and the dry residue was dissolved in $2 \mathrm{ml}$ of ethanol. An acetate buffer with $\mathrm{pH}=3.5$, ethanolic solutions of $0.2 \% \mathrm{FeCl}_{3}$ and $0.5 \% \alpha, \alpha^{\prime}$-dipyridyl were added to the ethanol extract. Absorbance of the mixture obtained in this way was measured after $20 \mathrm{~min}$, at a wavelength of $525 \mathrm{~nm}$. The concentration of tocopherols was determined based on a standard solution of $\alpha$-tocopherol (Sigma) within the range of $0.001-0.018 \mathrm{mg} \mathrm{x} \mathrm{ml}^{-1}$.

Statistical analysis was made using Statgraphic v 3.1 for Windows. Tuckey's test $(\mathrm{P}<0.05)$ was used to evaluate significant differences among the means from three replicates.

\section{RESULTS AND DISCUSSION}

The results obtained in this study showed that the level of total phenolic compounds depended on the concentration of calcium chloride (Fig. 3). The application of $\mathrm{CaCl}_{2}$ at a concentration of $0.1 \mathrm{M}$ caused a decrease in the level of total phenolic compounds, while an increase of this concentration to $0.2 \mathrm{M}$ had no significant effect on the accumulation of these compounds. The results obtained partially support the results obtained by R u i z et al. 2003 who, using much lower concentrations than those used in this study, showed a decrease in the level of phenolic compounds in tobacco leaves with increasing calcium ion concentrations (from 0.25 to $3 \mathrm{mM} \mathrm{CaCl}_{2}$ ). There are diverse reports on the effect of $\mathrm{Ca}^{2+}$ on the level of phenolic compounds in other plants. According to Castenada and Perez $1996, \mathrm{Ca}^{2+}$ plays a direct role in the synthesis of phenols. Those authors observed that foliar application of $10 \mu \mathrm{M} \mathrm{CaCl}_{2}$ increased the accumulation of phenols in lemon seedlings. 
The analysis of the results on the content of chlorogenic acid initially revealed a lower content of this acid following the application of $0.1 \mathrm{M} \mathrm{CaCl}_{2}$, while a significant increase in its content was noted after the application of $0.2 \mathrm{M} \mathrm{CaCl}_{2}$. The increase in the content of chlorogenic acid with an increase in the concentration of $\mathrm{CaCl}_{2}$ may be attributed to stimulation of the activity of L-phenylalanine ammonia-lyase by $\mathrm{Ca}^{2+}$ ions. According to a study by $\mathrm{R} \mathrm{u} \mathrm{iz} \mathrm{et} \mathrm{al.} \mathrm{2003,} \mathrm{the}$ highest concentration of $\mathrm{Ca}^{2+}$ caused the highest activity of L-phenylalanine ammonia-lyase that is the key enzyme in the synthesis of cinnamic acid derivatives, which also include chlorogenic acid.

The results of the effect of $\mathrm{CaCl}_{2}$ treatment on antioxidant activity of phenolic fractions isolated from the leaves of lettuce are presented in Figure 5. The application of $\mathrm{CaCl}_{2}$ solution on the plants 7 and 14 days before harvest caused a ca. 9\% decrease in antiradical abilities of the phenolic fraction obtained from the plants after $0.1 \mathrm{M} \mathrm{CaCl}_{2}$ treatment and a slight decrease (3\%) after using $0.2 \mathrm{M} \mathrm{CaCl}_{2}$ compared to the control.

Lettuce cv. Omega is also a good source of lipophilic vitamins such as provitamin A ( $\beta$-carotene), lutein and vitamin $\mathrm{E}$ (tocopherols) (Table 1). The dominant carotenoid in the leaves of the lettuce cultivar studied was $\beta$-carotene. Its content varied depending on the part of the leaf and $\mathrm{CaCl}_{2}$ concentration. The highest levels of $\beta$-carotene characterized the leaf blades without veins, about 2 times higher than in the whole leaves in the control plants. Spraying of lettuce with $\mathrm{CaCl}_{2}$ solution before harvest influenced only on the $\beta$-Carotene levels in the leaf blades without midrib. We noticed that $\beta$-carotene concentration decreased in the leaf blades about $20 \%$ compared to the control, but we did not notice any statistically significant differences in the concentration of this compound in the whole leaves of the plants sprayed with $\mathrm{CaCl}_{2}$ solution and in the control plants.

The next very important carotenoid in lettuce was lutein. The level of lutein in the control plants was 2.5 to 3 -fold lower than that of $\beta$-carotene. The level of lutein in this study was similar to the values given by other authors for butter lettuce $(\mathrm{Hart}$ and Scott, 1995; Nicole et al. 2004; Hamułka et al. 2005).

The results of the study of the effect of $\mathrm{CaCl}_{2}$ foliar treatment on lettuce indicated that in whole leaves only a slight increase in the levels of lutein was noticed after using $\mathrm{CaCl}_{2}$ solution at $0.1 \mathrm{M}$ and a decrease in the plants after treatment with $0.2 \mathrm{M} \mathrm{CaCl}_{2}$ (Table $1)$. These changes were not significant statistically. Higher differences were noticed in the concentration of lutein in the leaves without midrib. After treatment of the lettuce plants with $\mathrm{CaCl}_{2}$ at $0.1 \mathrm{M}$, the level of this carotenoid increased about $12 \%$, while at $0.2 \mathrm{M}$ it decreased about $43.5 \%$ compared to the control.

The content of tocopherols in lettuce leaves depends on the leaf type. It is the highest in the outer leaves (22.2 $\mu \mathrm{g} \mathrm{x} \mathrm{g}^{-1}$ f.m.), and lower in the central leaves $-9.2 \mu \mathrm{g} \mathrm{x} \mathrm{g}^{-1}$ f.m. (S z y mań s ka and $\mathrm{Kruk}$, 2008). These values are higher than the ones obtained in this study, as they are for leaves of whole lettuce heads (Table 1). This may be also due to inter-variety differences and the techniques applied for the determination of the tocopherol level.

The analysis of the results of the study on the effect of $\mathrm{CaCl}_{2}$ on the level of tocopherols in lettuce leaves revealed greater differences between the control plants and those treated with calcium chloride, compared to the differences observed in the changes in lutein content. The whole leaves of the plants treated with $\mathrm{CaCl}_{2}$ at a concentration of $0.1 \mathrm{M}$ were characterised by an $18 \%$ higher concentration of tocopherols and about $15 \%$ lower levels of these compounds after spraying with $0.2 \mathrm{M} \mathrm{CaCl}_{2}$ compared to the control plants.

In the literature, there is a lack of studies on the effect of $\mathrm{CaCl}_{2}$, applied in the form of foliar feeding, on the quality of lettuce 7 and 14 days before harvest, expressed in terms of vitamin value, and it does not permit a comparison of the results obtained with the results of studies by other authors.

The results of our earlier study on the application of $\mathrm{CaCl}_{2}$ on plants of sweet and semi-hot pepper cultivars during the vegetative growth stage showed a correlation between the content of $\beta$-carotene and tocopherols in control plants and in plants subjected to the effect of $\mathrm{CaCl}_{2}$ similar to that obtained in this study (Perucka and Materska, 2004).

In summary, the results obtained in the present study demonstrated that foliar application of $\mathrm{CaCl}_{2}$ on lettuce during the growing period had no significant effect on the level of $\beta$-carotene and lutein in whole leaves in terms of statistical significance. However, in the leaves of lettuce cv. Omega, after the application of $\mathrm{CaCl}_{2}$ at a concentration of $0.1 \mathrm{M}$, an increased level of vitamin $\mathrm{E}, \beta$-carotene and lutein was observed compared to the control. The greatest increase under the effect of $\mathrm{CaCl}_{2}$ application was noted in the level of tocopherols. Foliar $\mathrm{CaCl}_{2}$ treatment with $0.2 \mathrm{M}$ solution slowly decreased the content of vitamin $\mathrm{E}$ and carotenoid but enhanced the level of chlorogenic acid in lettuce leaves. Thus, the results indicated that controlled foliar treatment with $\mathrm{CaCl}_{2}$ can be used to enhance the level of antioxidants in lettuce. 
Effect of foliar calcium chloride treatment on the level of chlorogenic acid, $\beta$-carotene, lutein and tocopherols in lettuce... 69

Table 1.

The content of $\beta$-carotene, lutein and tocopherols in lettuce leaves $\left(\mu \mathrm{g} \times \mathrm{g}^{-1}\right.$ fresh weight)

\begin{tabular}{lcccccccc}
\hline Component & \multicolumn{3}{c}{ Whole leaves } & & & \multicolumn{2}{c}{ Leaves without midrib } \\
\hline & 0 & Ca1 & Ca2 & $\begin{array}{c}\text { LSD } \\
\mathrm{P}=0.05\end{array}$ & 0 & Ca1 & Ca2 & $\begin{array}{c}\text { LSD } \\
\mathrm{P}=0.05\end{array}$ \\
\hline $\begin{array}{l}\text { B-Carotene } \\
\text { Lutein }\end{array}$ & $27.35 A \pm 1.76$ & $27.71 A \pm 2.11$ & $25.11 A \pm 1.77$ & 2.37 & $43.79 B \pm 1.88$ & $35.34 A \pm 2.81$ & $35.10 A \pm 2.38$ & 2.99 \\
\hline Tocopherols & $5.53 A \pm 0.32$ & $6.71 B \pm 0.62$ & $4.73 C \pm 0.56$ & 0.65 & $12.06 A \pm 0.44$ & $11.99 A \pm 0.55$ & $9.07 B \pm 0.53$ & 0.64 \\
\hline $\begin{array}{l}\text { Dry matter } \\
(\%)\end{array}$ & $3.44 A \pm 0.19$ & $3.74 B \pm 0.18$ & $3.46 A \pm 0.12$ & 0.19 & $3.48 A \pm 0.89$ & $3.49 A \pm 0.25$ & $3.48 A \pm 0.15$ & 0.18 \\
\hline
\end{tabular}

Data are means \pm SD $(n=3)$

The same capital letters indicate no significant differences at $\mathrm{p}=0.05$ in the concentration of the analyzed compounds 0 - control $\mathrm{Ca} 1-\mathrm{CaCl}_{2} 0.1 \mathrm{M} \mathrm{Ca} 2-\mathrm{CaCl}_{2} 0.2 \mathrm{M}$

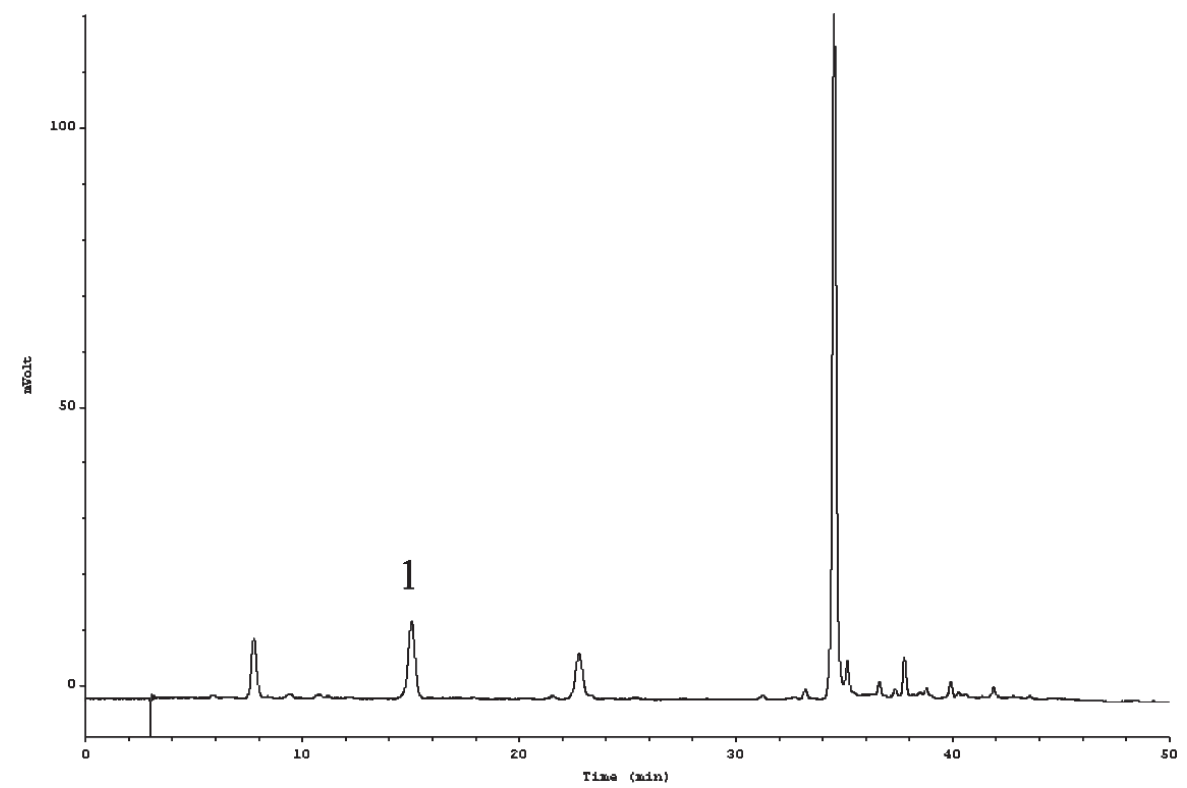

Fig. 1. Chromatogram of the phenolic fraction. 1 - chlorogenic acid.

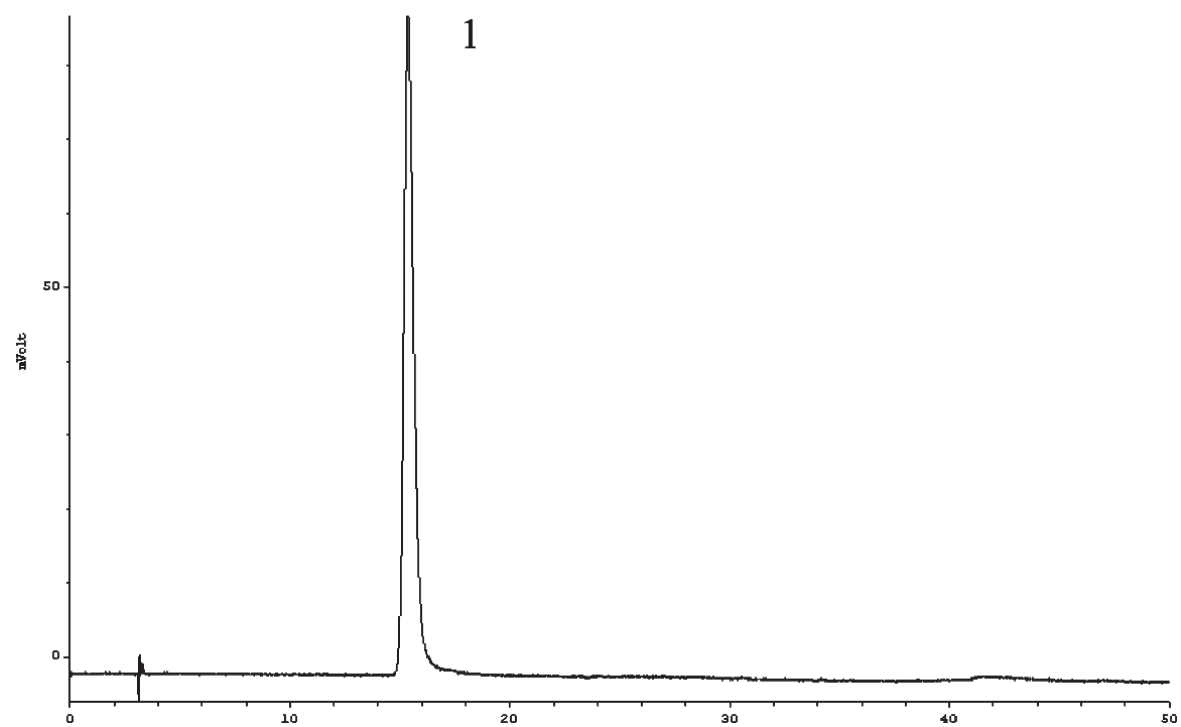

Fig. 2. Chromatogram of the standard of chlorogenic acid (1). 


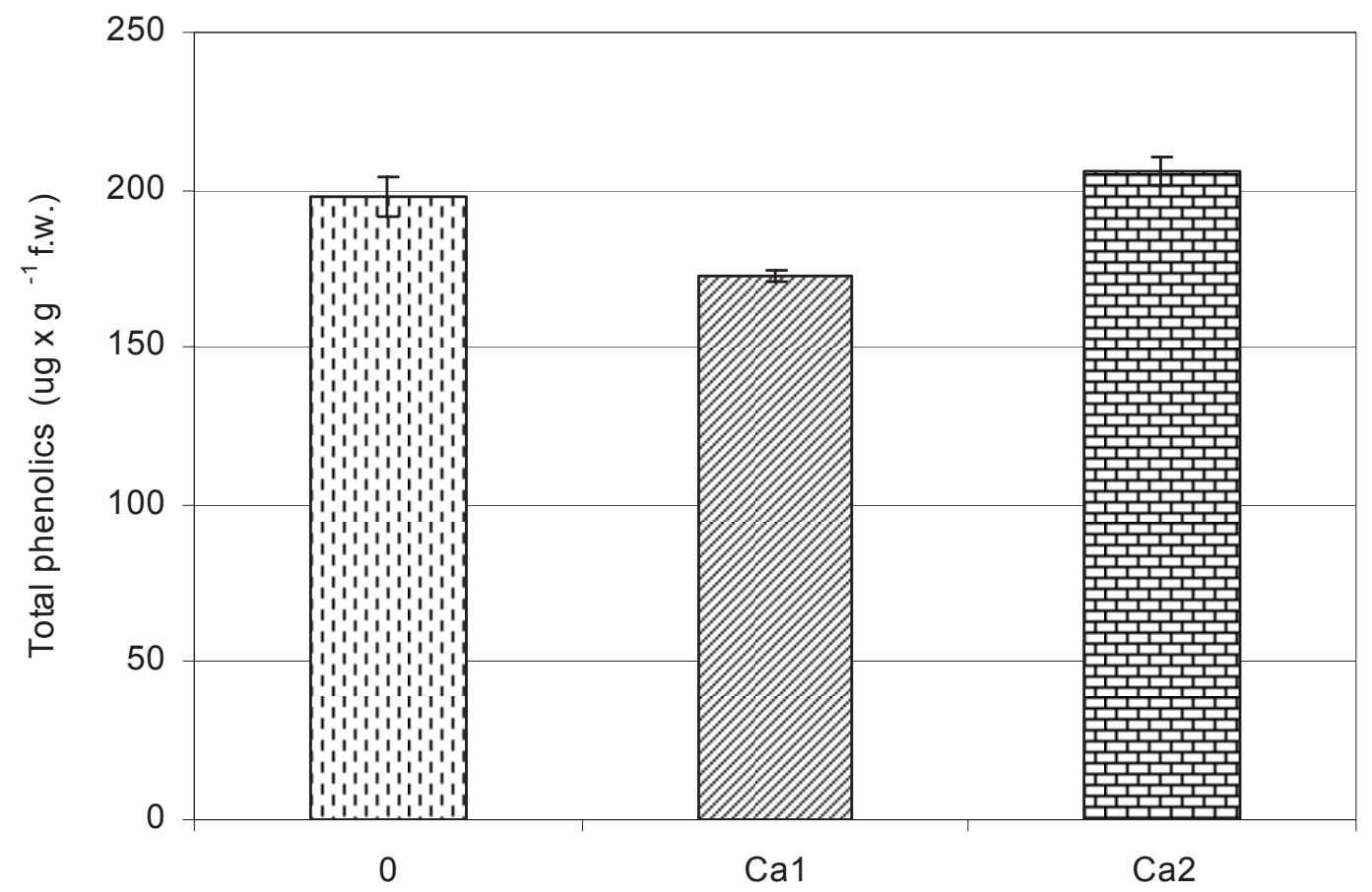

Fig. 3. Total phenolic contents in whole leaves of lettuce cv. Omega after spraying with $\mathrm{CaCl}_{2}$ solution $\left(\mu \mathrm{g} \times \mathrm{g}^{-1} \mathrm{f}\right.$.w.) Total phenolic contents were expressed as chlorogenic acid equivalent. Data are means \pm SD $(n=3)$. The least significant difference LSD $=0.19(\mathrm{p}=0.05)$.

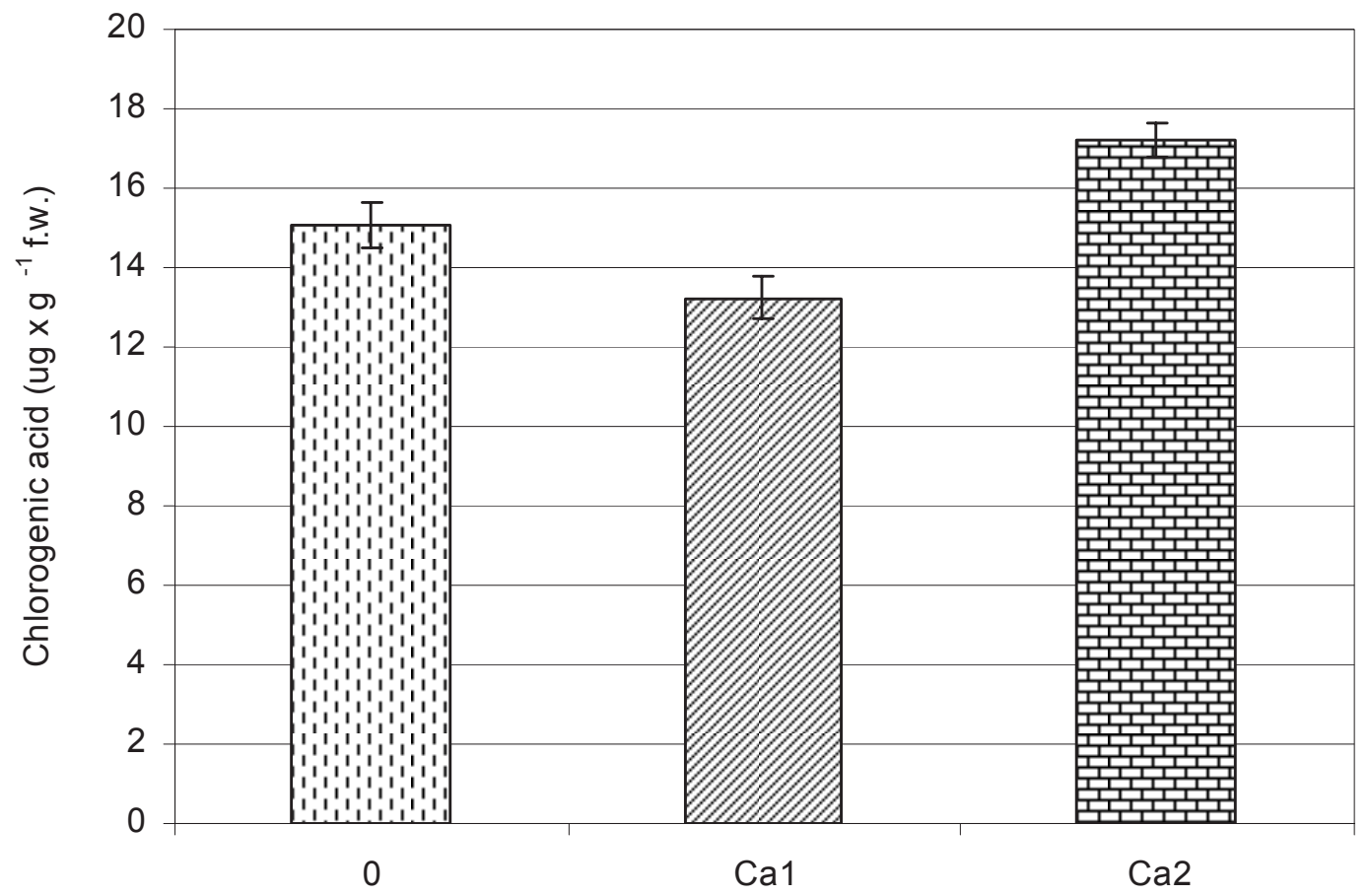

Fig. 4. Chlorogenic acid level in whole leaves of lettuce cv. Omega after spraying with $\mathrm{CaCl}_{2}$ solution $\left(\mu \mathrm{g} \times \mathrm{g}^{-1} \mathrm{f} . \mathrm{w}\right.$.) Data are means \pm SD $(n=3)$. The least significant difference LSD $=0.02(p=0.05)$. 


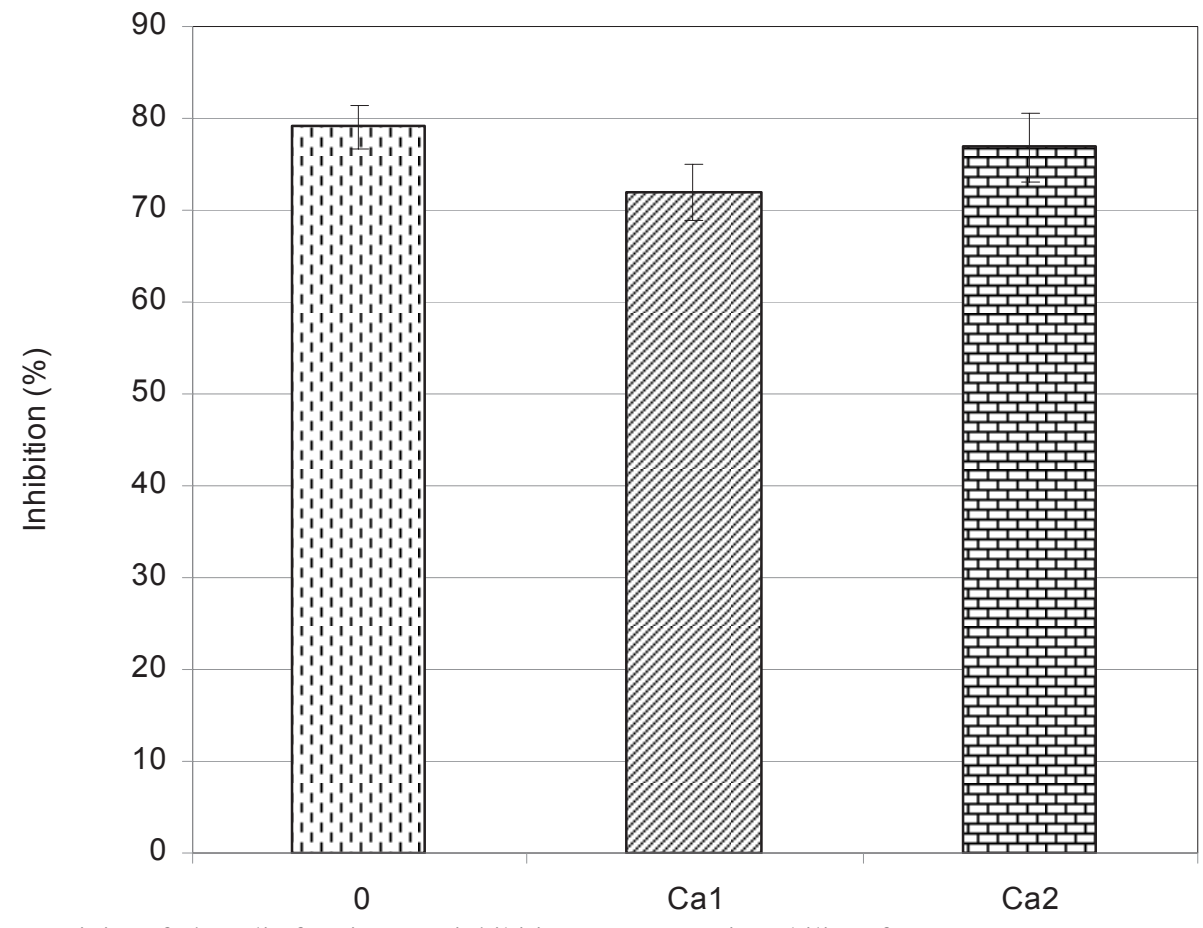

Fig. 5. Antioxidant activity of phenolic fractions (\% inhibition) as scavenging ability of DPPH*.

Data are means \pm SD $(n=3)$. The least significant difference LSD $=3.85(p=0.05)$.

\section{ACKNOWLEDGEMENTS}

Authors are thankful to Prof. Dr hab. Józef Nurzyński, Director of the Faculty of Cultivation and Fertilisation of Horticultural Plants, University of Life Sciences in Lublin, for his support in the greenhouse experiments.

\section{REFERENCES}

Block G., Patterson B., Subar A., 1992. Fruit, vegetables and cancer prevention: a review of the epidemiological evidence. Nutr. Cancer. 18: $1-29$.

Caldwell Ch.R., Britz S.J., 2006. Effect of supplemental ultraviolet radiation on the carotenoid and chlorophyll composition of green house-grown leaf lettuce (Lactuca sativa L.) cultivars. J. Food Comp. Anal. 19: 637-644.

Castaneda P., Perez L., 1996. Calcium ions promote the response of Citrus limon against fungal elicitors or wounding. Phytochem. 42 (3): 595-598.

Chen H., Yuegang Z., Deng Y., 2001. Separation and determination of flavonoids and other phenolic compounds in cranberry juice by high-performance liquid chromatography. J. Chromatogr. A, 913: 387-395.

Degl'Innocenti E., Guidi L., Pardossi A., Tog n on i F., 2005. Biochemical study of leaf browning in minimally processed leaves of lettuce (Lactuca sativa L. var. Acephala). J. Agric. Food Chem. 53: 9980 - 9984.

Degl'Innocenti E., Pardossi A ., Tognoni F., Guidi L., 2007. Physiological basis of sensivity to enzymatic browning in lettuce, escarole and rocket salad when stored as fresh-cut products. Food Chem. 104: 209-215.

Fergus on B., 1984. Calcium in plant senescence and fruit ripening. Plant Cell Environ. 7: 477-489.

Ferrante A., MaggIore T., 2007. Chlorophyll $a$ fluorescence measurements to evaluate storage time and temperature of Valeriana leaf vegetables. Postharvest Biol. Technol. 45: 73-80.

Frye r M.J., 1992. The antioxidant effects of thylakoid Vitamin E ( $\alpha$-tocopherol). Plant Cell Environ. 15: 381-392.

Gontier M.P., Remsey C., Scalbert A., Cheynier V., Suquel J.M., Poutanen K., Aura A., 2006. Microbial metabolism of caffeic acid and its esters chlorogenic acid and tartaric acid by human facial microbiota in vitro. Biomed \& Pharm. 60: 536-540.

Hamułka J., Koczara J., Gronek M., 2005. Lutein content of selected Polish foods and estimation of its intake. Pol. J. Food Nutr. Sci. 14/55 (2): 201-206.

Hart D.J., Scott K.J., 1995. Development and evaluation of an HPLC method for the analysis of carotenoids in foods, and the measurement of the carotenoid content of vegetables and fruits commonly consumed in the UK. Food Chem. 54: 101-111.

Hofius D., Hajirezaei M.R.,Geiger M., Tschiersch H., Melzer M., Sonnewald U., 2004. RNAi-mediated tocopherol deficiency impairs photoassimilate export in transgenic potato plants. Plant Physiol. 135: 1256-1268.

Kimura K., Rodriguez-A maya D.B., 2003. Carotenoid composition of hydroponic leafy vegetables. J. Agric. Food Chem. 51: 2603-2607. 
Kruk J., Hollander-Czytko H., Oettmeier W., Trebst A., 2005. Tocopherol as singlet oxygen scavenger in photosystem II. J. Plant Physiol. 162: 749 757.

Llorach R., Tomas-Barberan F.A., Ferreres F., 2004. Lettuce and chicory byproducts as a source of antioxidant phenolic extracts. J. Agric. Food Chem. 52: 5109-5116.

Martin-Diana A.B., Rico D., Barry-Ryan C., Frias J.M., Henehan G.T.M., Barat J.M., 2007. Efficacy of steamer jet - injection as alternative to chlorine in fresh - cut lettuce. Postharvest Biol. Technol. 45: 97- 107.

Michałojć Z.M., Horodko K., 2006. Wpływ dokarmiania pozakorzeniowego wapniem na plonowanie i skład chemiczny papryki słodkiej. / The effect of non-root feeding with calcium on yield and chemical composition of sweet pepper. Acta Agroph. 7 (3): 671-679.

Moeller S.M., Jacques P.F., Blumberg J.B., 2000. The potential role of dietary xantophylls in cataracta and age - related macular degeneration. J. Am. Coll. Nutr. 19: 522-527.

Munne-Bosch S., Alegre L., 2002. The function of tocopherols and tocotrienols in plants. Crit. Rev. Plant Sci. 21: 31-57.

Müller-Mulot M.A., 1968. New method for the quantitative determination of added $\alpha$-tocopherol acetate in greenstuffs. Zeit. Analyt.Chem. 6: 378-388.

Nicolle C., Carnat A., FraIsse D., Lamaison J.L., Rock E., Michel H., Amouroux P., Remesy $\mathrm{Ch} ., 2004$. Characterisation and variation of antioxidant micronutrients in lettuce (Lactuca sativa folium). J. Sci. Food Agric. 84: 2061-2069.

Niizu P.Y., Rodriguez-A maya D.B., 2005. New data on the carotenoid composition of raw salad vegetables. J. Food Comp. Anal. 18: 739 - 749.

Olthof M.R., Hollman P., Katan M.B., 2001. Chlorogenic acid, quercetin-3-rutinoside and black tea phenols are extensively metabolized in humans. J. Nutr. 133: 1806.

Peru cka I., 1996. Ethefon-induced changes in accumulation of carotenoids in red pepper fruit (Capsicum annum $\mathrm{L}$ ). Pol. J. Food Nutr. 5/46: 61-68.

Perucka I., Materska M., 2004. Wpływ dolistnego stosowania jonów $\mathrm{Ca}^{2+}$ oraz procesu suszenia na zawartość $\alpha$-tokoferolu, $\beta$-karotenu i ksantofili w owocach papryki słodkiej. / The effect of foliar application of $\mathrm{Ca}^{2+}$ ions and drying process on the content of $\alpha$-tocopherol, $\beta$-carotene and xanthophylls in sweet pepper fruits. Żywność Nauka Technologia Jakość, 4 (4): 114-122.

Perucka I., Nurzyński J., Olszówka K., 2007. Wpływ $\mathrm{CaCl}_{2}$ na zawartość składników mineralnych w liściach sałaty. / The effect of $\mathrm{CaCl}_{2}$ on nutrient content in lettuce leaves. J. Elementol. 12 (3): 181-190 (in Polish).

Ragaert P., Verbeke W., Devlieghere F., Debevere J., 2004. Consumer perception and choice of minimally processed vegetables and packed fruits. Food Qual. Pref. 15: 259 - 270.
Rodriguez de Sotillo D.V., Hadley M., 2002. Chlorogenic acid modifies plasma and liver concentrations of: cholesterol triacyloglycerol and minerals in (fa/fa)Zucker rats. J. Nutr. Bioch. 13: 717-726.

Ruiz J.M., Rivero R.M., Lopez-Cantarero I., Romero L., 2003. Role of $\mathrm{Ca}^{2+}$ in the metabolism of phenolic compounds in tobacco leaves (Nicotiana tabacum L.). Plant Growth Reg. 41: 173-177.

Ruperez F.J., Martin D., Herrera E., Barbas C., 2001. Chromatographic analysis of $\alpha$-tocopherol and related compounds in various matrices. J. Chromatogr. A 935: 45-69.

Steinmetz K.A., Potter J.D., 1991. Vegetables, fruits and cancer. I. Epidemiology. Cancer Causes Control. 2: 325-357.

Szymańska R., Kruk J., 2008. Tocopherol content and isomers' composition in selected plant species. Plant Phys. Bioch. 46: 29-33.

Trebst A., Depka B., Hollander-Czytko H., 2002. A specific role for tocopherol and of chemical singlet oxygen quenchers in the maintenance of photosyetem II structure and function Chlamydomonas reinhardtii. FEBS Lett. 516: 156-160.

\section{Wpływ dolistnego stosowania chlorku wapnia na poziom kwasu chlorogenowego, $\beta$-karotenu, luteiny i tokoferoli w liściach sałaty (Lactuca sativa $\mathbf{L}$.)}

\section{Streszczenie}

Celem badań było określenie wpływu dolistnego stosowania $\mathrm{CaCl}_{2}$ na poziom $\beta$-karotenu, luteiny, tokoferoli i związków fenolowych w liściach sałaty odmiany Omega (Lactuca sativa L.). Doświadczenie wazonowe przeprowadzono w szklarni Katedry Uprawy i Nawożenia Roślin Ogrodniczych Uniwersytetu Przyrodniczego w Lublinie. Podczas okresu wzrostu, 14 i 7 dni przed zbiorem, rośliny potraktowano roztworem $\mathrm{CaCl}_{2}$ o stężeniu 0.1 M i 0.2 M. Rośliny kontrolne opryskano wodą. Do analizy wykorzystano całe liście oraz blaszki liściowe bez głównego nerwu liściowego. Otrzymane wyniki wskazują, że liście sałaty odmiany Omega stanowią dobre źródło związków fenolowych, karotenoidów i tokoferoli. Dominującym karotenoidem w sałacie odmiany Omega był $\beta$-karoten. Dolistne stosowanie $\mathrm{CaCl}_{2}$ na rośliny nie miało istotnego wpływu na poziom $\beta$-karotenu i luteiny w całych liściach. Zawartości tokoferoli, sumy związków fenolowych i kwasu chlorogenowego zależały od stężenia $\mathrm{CaCl}_{2}$. Zastosowanie $\mathrm{CaCl}_{2} \mathrm{O}$ stężeniu $0.1 \mathrm{M}$ spowodowało spadek poziomu sumy związków fenolowych i kwasu chlorogenowego oraz wzrost zawartości tokoferoli. Natomiast potraktowanie roślin $0.2 \mathrm{M}$ roztworem $\mathrm{CaCl}_{2}$ spowodowało spadek stężenia tokoferoli i wzrost zawartości kwasu chlorogenowego i sumy związków fenolowych. 